\title{
Fundamental niche differentiation in subspecies of Sarcocornia perennis on a salt marsh elevational gradient
}

\author{
Susana Redondo-Gómez ${ }^{1, *}$, Jesús M. Castillo ${ }^{1}$, Carlos J. Luque ${ }^{2}$, Teresa Luque ${ }^{1}$, \\ M. Enrique Figueroa ${ }^{1}$, Anthony J. Davy ${ }^{3}$ \\ ${ }^{1}$ Departamento de Biología Vegetal y Ecología, Facultad de Biología, Universidad de Sevilla, Apartado 1095, \\ 41080 Sevilla, Spain \\ ${ }^{2}$ Departamento de Biología Ambiental y Salud Pública, Facultad de Ciencias Experimentales, Universidad de Huelva, \\ 21071 Huelva, Spain \\ ${ }^{3}$ Centre for Ecology, Evolution and Conservation, School of Biological Sciences, University of East Anglia, \\ Norwich Research Park, Norwich NR4 7TJ, UK
}

\begin{abstract}
Selection pressures associated with strong environmental gradients on salt marshes provide a mechanism for the genetic subdivision of species. We investigated the importance of differentiated habitat niches in explaining the distributions of 2 forms of the halophyte Sarcocornia perennis: ssp. perennis in lower/middle marshes and the Iberian endemic ssp. alpini on more elevated salines. The fundamental niches of the 2 subspecies were investigated at the Odiel marshes, SW Spain with an experimental transplantation to 4 points along an elevation gradient. Subspecies perennis survived at the 3 lower elevations, from +2.26 to $+2.84 \mathrm{~m}$ relative to Spanish Hydrographic Zero (SHZ) and flowered only at the highest of these locations. Subspecies (ssp.) alpini survived only at the 2 higher elevations (+2.84 and +3.65 m SHZ), flowering only at the highest location. As expected, sediment redox potential increased at transplant sites up the marsh, with decreasing tidal submergence; sediment salinity also increased and its water content decreased with increasing elevation. Sediment $\mathrm{pH}$ also declined with increasing elevation. Air conditions in the Mediterranean summer become cooler and moister with proximity to the sea. The failure of ssp. alpini to survive below its limit was attributed to its intolerance of increasingly hypoxic, reducing sediments. The failure of ssp. perennis to survive above its limit was associated with hypersalinity and water stress in summer. The fundamental niches of the 2 subspecies showed limited overlap (i.e. one transplantation site): that of ssp. perennis approximates the realized niche observed in the field but the realized niche of ssp. alpini appears to be more restricted than its fundamental niche.
\end{abstract}

KEY WORDS: Halophyte $\cdot$ Realized niche $\cdot$ Redox potential $\cdot$ Salinity $\cdot$ Transplantation experiment

\section{INTRODUCTION}

The selection pressures associated with strong environmental gradients provide a mechanism for the genetic subdivision of species, assuming a degree of reproductive isolation between local populations. Salt marshes represent prime examples of such gradients, especially in relation to tidal submergence, sediment redox potential and salinity. For instance, genetically differentiated populations of the predominantly inbreeding, annual halophytes Salicornia spp. have been shown to vary in fitness in different local habits on salt marshes (Davy \& Smith 1985, Davy et al. 2001). The extent of divergence in habitat niche between genetically differentiated populations or types is of particular interest in explaining current distributions; it is important in maintaining genetic diversity within species and, ultimately, species diversity itself.

Sarcocornia perennis (Miller) A. J. Scott is a perennial halophyte that exists as 2 morphologically distinct subspecies in the Iberian Peninsula (Castroviejo 1990). Subspecies (ssp.) perennis, with a prostrate habit and 
low, flexible flowering shoots, is widely distributed around the coasts of Europe; in contrast, ssp. alpini (Lag.) Castroviejo has taller, stiff, tree-like flowering shoots and is endemic to the Iberian Peninsula and the Balearic Islands. Analysis of randomly amplified polymorphic DNA (RAPDs) has shown clear genetic differentiation and strongly supports the recognition of these subspecies (Davy et al. 2006). Their distribution suggests that they occupy rather different saline habitats with different plant communities. S. perennis ssp. perennis usually grows in regularly flooded low marshes and, especially through its interactions with Spartina maritima, can play a distinctive role in the successional development of salt marshes in SW Spain (Castellanos et al. 1994, Figueroa et al. 2003). Subspecies (ssp.) alpini is normally found on non-tidal saline steppes or near the upper limits of the tidal range, but is never found in sites directly bathed with seawater (Castroviejo 1990). The 2 subspecies were never found growing together in the field. The distributions of plants and their communities along the elevation gradient of salt marshes are related to the ability of the individual species to tolerate certain ranges of environmental conditions associated with the frequency and duration of tidal inundation, particularly salinity and sediment soil redox potential (Castillo et al. 2000, Stribling et al. 2006). Such differences in tolerance can be considered representative of divergence in their fundamental niches. On the other hand, the zonation of individual species on salt marshes may be determined to a considerable extent by the interactions with other species, both positive and negative, that define their realized niches (Bertness 1991).

The aim of this study was to investigate whether differences in fundamental niches were sufficient to explain the differential distribution of the 2 subspecies of Sarcocornia perennis on a marsh elevational gradient. The specific objectives were (1) to examine the survival and flowering success of the 2 subspecies after transplantation to a range of elevations in relation to the tidal frame in the absence of competing or facilitating plant species; and (2) to measure niche dimensions of the physicochemical environment over the same elevational range on the marsh in order to explain differential survival.

\section{MATERIALS AND METHODS}

Study location. This experiment was located on a gently sloping intertidal plain in the Odiel marshes, which are situated on the joint estuary of the Odiel and Tinto rivers at Huelva, on the Atlantic coast of SW Spain $\left(37^{\circ} 15^{\prime} \mathrm{N}, 6^{\circ} 58^{\prime} \mathrm{W}\right)$. This coast is mesotidal; tides are semidiurnal with a mean range of $2.10 \mathrm{~m}$ and a
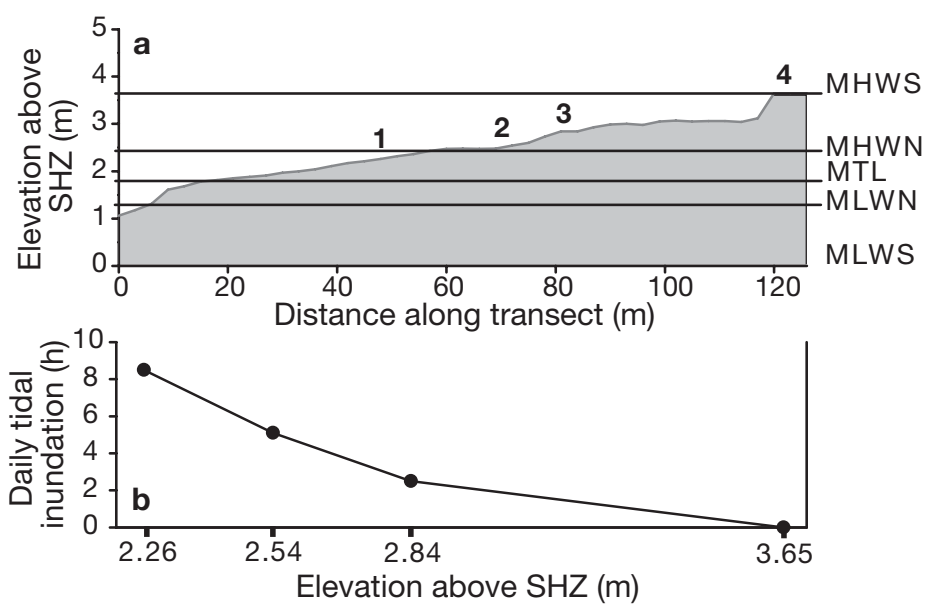

Fig. 1. Elevational transect above Spanish Hydrographic Zero (SHZ) across an intertidal gradient at the Odiel Marshes, SW Spain, $120 \mathrm{~m}$ long, perpendicular to the tidal line. (a) Locations of the 4 transplant points in relation to topography: MHWS, mean high water spring tidal level; MHWN, mean high water neap tidal level; MTL, mean tidal level; MLWN, mean low water neap tidal level; MLWS, mean low water spring tidal level (means are long-term averages for this location). (b) Mean duration of daily tidal inundation

mean spring tidal range of $2.97 \mathrm{~m}$, representing a range of 0.40 to $3.37 \mathrm{~m}$ above Spanish Hydrographic Zero (SHZ). Mean sea level at Huelva is $+1.85 \mathrm{~m}$ relative to SHZ (Castellanos et al. 1994).

Transplant experiment. Both subspecies of Sarcocornia perennis grow as concentrically expanding clumps of articulated, succulent, photosynthetic stems, attached to extensive rhizome and root systems. S. perennis ssp. perennis was obtained from a low-marsh site (elevation +2.54 m SHZ) at Odiel and ssp. alpini from a high-marsh locality in the Guadalquivir Marshes (elevation $+4.00 \mathrm{~m} \mathrm{SHZ;} 37^{\circ} 7^{\prime} \mathrm{N}, 6^{\circ} 10^{\prime} \mathrm{W}$ ) in April 2002. Clumps of each subspecies of about $20 \mathrm{~cm}$ diameter were first transplanted to a common environment in the Odiel marshes at an elevation of ca. $+3.35 \mathrm{~m} \mathrm{SHZ}$ for a month in order to subject the plants to a similar degree of transplantation shock. No attempt was made to remove local sediment adhering to the clumps, as this would have damaged the roots. In May 2002 a transect of $120 \mathrm{~m}$ was established perpendicular to the tidal line with a mean inclination of ca. $2.5 \%$, and a height difference of $139 \mathrm{~cm}$. Elevation was surveyed to a resolution of $2 \mathrm{~cm}$ with a Leica NA 820 theodolite (Leica Instruments). Measurements were taken at $3 \mathrm{~m}$ intervals along the transect. Reference points were determined in relation to measurements of tidal extremes (Ranwell et al. 1964). Three transplantation points of increasing elevation were established on the intertidal plain, and a higher 4th point was located on a bank above the highest astronomical tides (Fig. 1). Then 5 clumps of each subspecies were transplanted again to each of the 4 lo- 
cations along the transect in May 2002. Clumps were planted to a depth of 10 to $15 \mathrm{~cm}$, in a row parallel to the tidal line, with $0.5 \mathrm{~m}$ spacing between them. All transplantations were carried out in areas that had been cleared of other vegetation, so that selection pressures on transplanted clumps would be largely abiotic. Survival and flowering of all clumps was determined in October 2002; a clump was considered dead when no green stems remained.

Environmental measurements. Measurements of sediment conductivity $(\mathrm{n}=5), \mathrm{pH}(\mathrm{n}=5)$ and redox potential $(\mathrm{n}=15)$ were obtained at low tide on bare sediments from each of 2 rooting depths ( 0 to 10 and 10 to $20 \mathrm{~cm}$; Figueroa et al. 2003) at all 4 points along the transect in June 2002. Conductivity of the sediment was determined in the laboratory with a conductivity meter (Crison-522) after diluting with distilled water (1:1). Redox potential and $\mathrm{pH}$ of the sediment were determined with a portable meter and electrode system calibrated in the field (Crison $\mathrm{pH} / \mathrm{mV} \mathrm{p}-506$ ). Soil water content was determined at each point from samples taken from the upper $15 \mathrm{~cm}$ of sediment $(\mathrm{n}=5)$. Samples were weighed before and after drying at $80^{\circ} \mathrm{C}$ for $48 \mathrm{~h}$. Measurements of air temperature and relative humidity were taken at $1.5 \mathrm{~m}$ above ground at each transplantation point with a thermohygrometer (Elka FTM10) in June, July and October 2002 (these measurements were taken on one occasion during the month).

Statistical analysis. Statistical analysis was carried out using Statistica v. 6.0 (Statsoft). Pearson coefficients were calculated to assess correlation between variables. Data were analysed by 1 -way analysis of variance ( $F$-test). Data were tested for normality with the Kolmogorov-Smirnov test and for homogeneity of variance with the Brown-Forsythe test. Significant test results were followed by Tukey tests to identify important contrasts. Differences between environmental measurements at the 2 sampling depths were compared using a Student's $t$-test.

\section{RESULTS}

\section{Environmental measurements}

Sediment redox potential was positively correlated with topographic elevation at both sampling depths (Fig. 2a). At the lowest and highest transplantation points there was no significant difference between redox potential at the 2 sampling depths, but at the 2 middle points, surface sediments were significantly less reduced than at the deeper ones $(t=2.3, \mathrm{p}<0.05$; $t=3.7, \mathrm{p}<0.001$, respectively).

Sediment water content decreased with topographic elevation (Fig. 2b). At the highest transplant point it dropped to ca. $30 \%$, significantly lower than that at the other points $(F=59.3, \mathrm{p}<0.0001)$.

Sediment $\mathrm{pH}$ decreased systematically with increasing elevation above SHZ, both at the surface and at depth. In the surface sediments, it ranged from 6.7 to 7.4 and in the deeper sediments, from 6.7 to 7.9

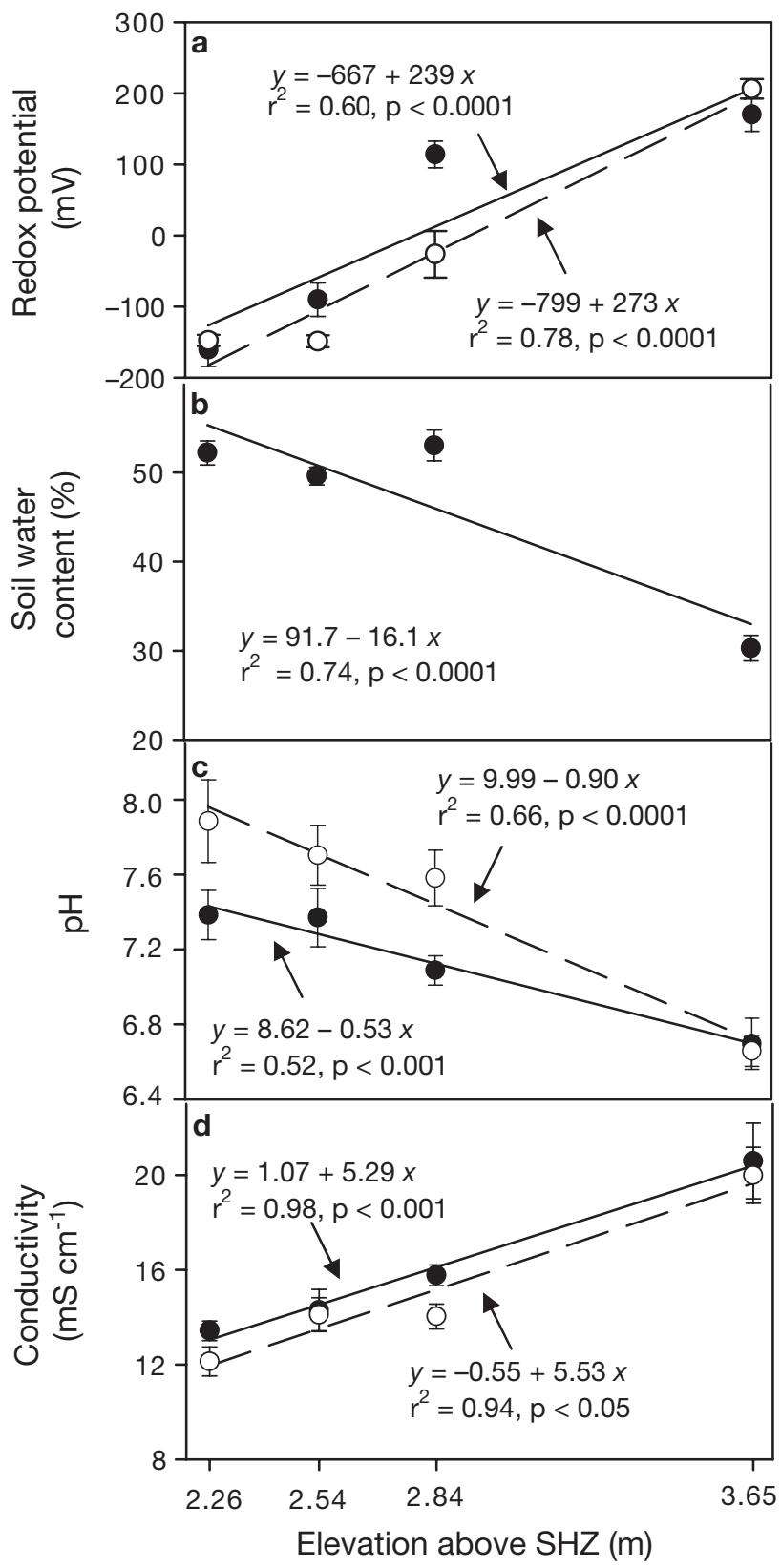

Fig. 2. Relationships between environmental measurements and elevation above Spanish Hydrographic Zero (SHZ) at 4 transplant points at the Odiel marshes, SW Spain: (a) sediment redox potential $(\mathrm{n}=15)$; $(\mathrm{b})$ soil water content $(\mathrm{n}=5)$; (c) $\mathrm{pH}(\mathrm{n}=5)$; and (d) conductivity $(\mathrm{n}=5)$. Continuous and dashed lines correspond to the fitted regression equations for sediment conditions within 0 to $10 \mathrm{~cm}(\bullet)$ and 10 to $20 \mathrm{~cm}(\mathrm{O})$ sediment depths, respectively 


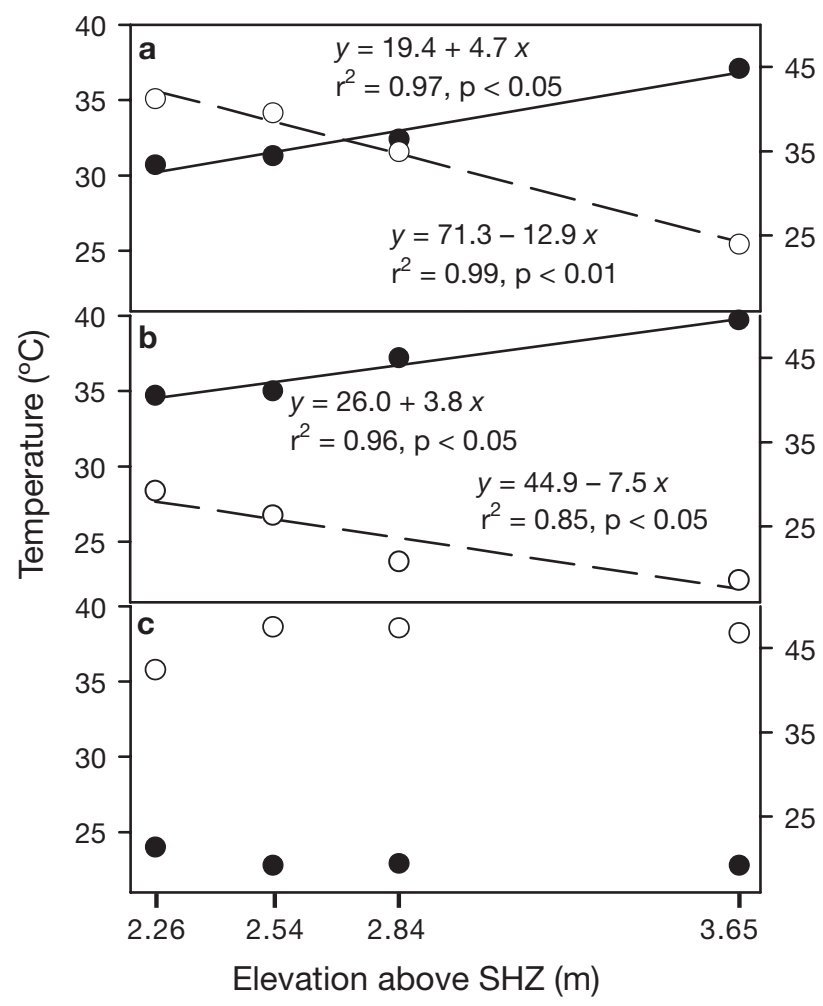

Fig. 3. Air temperature (०) and air relative humidity (O) in relation to elevation above Spanish Hydrographic Zero (SHZ) at 4 transplant points at the Odiel marshes, SW Spain. Measurements in (a) June, (b) July, and (c) October. Continuous and dashed lines correspond to the fitted regression equations for temperature and humidity, respectively

(Fig. 2c). Sediment $\mathrm{pH}$ at the surface of the highest transplant point was significantly lower than at the 2 transplant points closest to the shoreline $(F=6.2, \mathrm{p}<$ 0.01). In the deeper sediments, $\mathrm{pH}$ was significantly lower at the highest point than all the rest $(F=11.61$, $\mathrm{p}<0.001)$.

Electrical conductivity of sediment interstitial water (salinity) showed no difference between surface and deeper sediments, but at both depths there were significant positive relationships with increasing elevation, reaching around $20 \mathrm{mS} \mathrm{cm}^{-1}$ at the highest transplant point (Fig. 2d).

Air temperature during June and July was correlated positively with topographic elevation, and air humidity at that time was correlated negatively with elevation. The differences between the points closest and farthest from the sea were as great as 5 to $6^{\circ} \mathrm{C}$ and 10 to $17 \%$ humidity (Fig. 3). At the highest transplantation point, temperatures reached $40^{\circ} \mathrm{C}$ with a relative humidity of only $19 \%$. In October, the temperature decreased to around $23^{\circ} \mathrm{C}$ and the humidity increased to almost $45 \%$, but there were no relationships with elevation at that time.

\section{Transplant performance}

Survival of a subspecies at any transplant site did not show any variation among the 5 replicate clumps: either all survived or none did. All of the Sarcocornia perennis ssp. perennis clumps survived at the 3 lowest transplant points but none survived at the highest. Conversely, $100 \%$ of ssp. alpini clumps survived at the higher points 3 and 4 , but none at the 2 lower ones. Thus, transplantation point 3 was the only location at which the range of survival of the 2 subspecies overlapped. Furthermore, this was the only elevation at which ssp. perennis produced flowers (100\% of the clumps), whereas ssp. alpini only produced flowers $(80 \%$ of the clumps) at the highest transplantation point.

\section{DISCUSSION}

The need for the niche concept has been questioned, particularly for highly diverse communities where there is limited environmental heterogeneity (e.g. Hubbell 2006); however, for relatively simple communities in ecosystems with strong environmental gradients, such as coastal salt marshes or sand dunes, it provides a useful theoretical framework (e.g. Mouillot et al. 2004). The 2 subspecies of Sarcocornia perennis showed clear habitat differentiation along a salt-marsh elevation gradient. Survival at any transplantation level was 'all or nothing' for a particular subspecies, and there was apparently only a relatively narrow region in the upper marsh where their ranges of tolerance overlapped. The survival of the 2 subspecies after transplantation also corresponded closely with their observed distributions in saline habitats. Clumps of $S$. perennis ssp. perennis all survived at elevations between +2.26 and $+2.84 \mathrm{~m} \mathrm{SHZ}$, but not higher. This conforms with its behaviour in the rapid successional development of new marsh from low-lying intertidal mud flats: in a well-drained lagoon, ssp. perennis could invade the tops of the colonizing tussocks of Spartina maritima when they accreted to an elevation of ca. $+2.0 \mathrm{~m} \mathrm{SHZ}$, and it could achieve dominance by the time the tops of the rhizomes had reached $+2.8 \mathrm{~m}$ (Figueroa et al. 2003). Sánchez et al. (1996) reported a mean elevation for ssp. perennis of ca. $+3.55 \mathrm{~m} \mathrm{SHZ} \mathrm{on}$ marshes in Galicia, NW Spain, but the tidal regime is different there, as mean sea level is at ca. $+2.35 \mathrm{~m} \mathrm{SHZ}$. Flowering of ssp. perennis normally occurs under conditions favourable for growth (Davy et al. 2006) and, under experimental conditions, prolonged inundation of ssp. perennis prevents flowering and seed production (Adams \& Bate 1994). It is notable in our experiment that, despite $100 \%$ survival at the lower elevations, ssp. perennis only produced flowers when 
mean daily inundation did not exceed $5 \mathrm{~h}$. Hence, it appeared to benefit from the lower flooding frequency. In complete contrast, ssp. alpini transplants could not survive below $+2.84 \mathrm{~m} \mathrm{SHZ}$, implying tolerance of a mean daily submergence of only $2.5 \mathrm{~h}$ by vegetative plants. Furthermore, ssp. alpini only flowered when above the normal tidal range (+3.65 $\mathrm{m} \mathrm{SHZ),} \mathrm{a} \mathrm{result} \mathrm{which} \mathrm{corre-}$ sponds with reports of it never being found in sites directly bathed with seawater (Castroviejo 1990).

Sediment redox potential declined from strongly oxidizing values (ca. $+200 \mathrm{mV}$ ) to strongly reducing values (ca. $-150 \mathrm{mV}$ ) at transplantation locations of decreasing elevation and increasing tidal inundation, a trend reported previously for different parts of the Odiel marshes (Castellanos et al. 1994, Castillo et al. 2000, Figueroa et al. 2003) and salt marshes generally. Clumps of transplanted Sarcocornia perennis ssp. perennis thus survived sediment redox potentials as low as ca. $-150 \mathrm{mV}$. Previous work at the Odiel marshes has suggested that colonization of accreting Spartina maritima tussocks by seedlings of ssp. perennis requires positive surface redox values, although they may remain as low as $-180 \mathrm{mV}$ at depths of 10 to $20 \mathrm{~cm}$ (Castellanos et al. 1994). The root environment of ssp. perennis at Odiel was consistently oxidizing later in the succession, when it became dominant with increasing elevation (Figueroa et al. 2003). However, the present experiment shows that transplanted clumps of ssp. perennis are more tolerant of lower redox potentials than those of ssp. alpini, which only survived where surface conditions were oxidizing and the deeper sediments had a redox potential no lower than ca. $-30 \mathrm{mV}$. Plants can survive hypoxic, flooded environments using a range of mechanisms (Jackson \& Colmer 2005); these include tolerance of the plant cells, tissues, and organs to anoxia, manifested at a molecular level (Gibbs \& Greenway 2003), the ability to prevent or repair oxidative damage during episodes of re-aeration (Blokhina et al. 2003), and the avoidance of oxygen deficiency by internal aeration through aerenchyma (Jackson \& Armstrong 1999). Aerenchyma has not been observed in the stems of either subspecies when grown in aerobic conditions (Redondo-Gómez et al. 2005), but it might be produced in response to oxygen deficiency. $S$. perennis ssp. perennis characteristically roots at the nodes (Davy et al. 2006), unlike ssp. alpini. Adventitious roots produced under hypoxic conditions may develop aerenchyma (Aschi-Smith et al. 2003), and superficial rooting is also likely to be advantageous.

If differential tolerance of hypoxia and reducing conditions associated with increasing tidal submergence accounts for the lower limits of the subspecies on the elevation transect, what limits Sarcocornia perennis ssp. perennis at the highest parts? The explanation is likely to involve the gradients of increasing sediment salinity and decreasing sediment water content with greater topographic elevation. In the Mediterranean summer, evapotranspiration greatly exceeded precipitation, leading to hypersalinity as the tidal influence declined; lower in the tidal range, salinity remained more similar to that of seawater. In addition, proximity to the sea ameliorated the climatic extremes of summer, resulting in lower average air temperatures and higher average air humidity at the lower points along the transect. Hence, ssp. perennis at the highest location along the transect would have been exposed to highly adverse conditions in terms of its water relations (hypersalinity, high temperatures and low humidity) that ssp. alpini can clearly tolerate. S. perennis ssp. alpini has a cylinder of photosynthetically active, chlorophyllous tissue lying immediately within the endodermis; this tissue is composed of small round cells that contain numerous chloroplasts (Redondo-Gómez et al. 2005). This feature is absent from ssp. perennis, although it is shared with Sarcocornia fruticosa, a halophyte with extremely high tolerance of hypersaline conditions (Redondo-Gómez et al. 2006). Thus, it is possible that this photosynthetic cylinder could play some role in adaptation to these environmental stresses.

Intriguingly, there was also a trend of declining $\mathrm{pH}$ along the transect at locations further away from the influence of the sea. The sediment $\mathrm{pH}$ varied with depth as well, with deeper sediments having higher $\mathrm{pH}$ than surface sediments at lower elevations close to the sea. This difference diminished with increasing elevation until there was no difference at the highest location. The $\mathrm{pH}$ trends might be related to greater organic matter decomposition or reduced seawater carbonate buffering, but there is no evidence that $\mathrm{pH}$ influenced the distribution of either subspecies. Differences between vegetation zones in surface-sediment $\mathrm{pH}$ are uncommon, but indirect factors such as organic content accumulation in older marshes and salt deposition/leaching in depressions can produce differences of 1 to $4 \mathrm{pH}$ units (Costa et al. 2003).

The transplantation experiment shows a clear differentiation between the fundamental niches of the 2 subspecies, with relatively little overlap, on an environmental gradient. The fundamental niche of Sarcocornia perennis ssp. perennis approximates the realized niche observed in the field, even though its colonization can be facilitated on the lower marsh by Spartina maritima (Castellanos et al. 1994) and it may also have interactions with other species. The realized niche of ssp. alpini might be more restricted than its fundamental niche, since it survived on sites lower in the marsh than where it can be found in the field, suggesting possible exclusion by interspecific competition. However, it did not flower at the lower site and 
the experiment, by virtue of transplanting vegetative clumps, did not take into account the regeneration niches (Grubb 1977) of either subspecies. In this respect, it is interesting that ssp. perennis can germinate at salinities double that of seawater (Redondo et al. 2004), even though it appears to be effectively excluded from hypersaline sites. Further studies are necessary to investigate competitive relationships between the 2 subspecies and with other halophytes at locations where they might potentially co-exist. However, in contrast to the patterns of plant distribution in many salt marshes (e.g. Bertness 1991, Castillo et al. 2000), these results indicate that an upper limit (of ssp. perennis) may be fundamentally determined by abiotic stress, and that biotic interactions might restrict distribution at a lower limit (of ssp. alpini).

Their relative environmental tolerances might cast some light on the evolutionary relationship between the 2 subspecies. Sarcocornia perennis ssp. alpini is reminiscent of Sarcocornia fruticosa in its growth form and restriction to upper marshes or saline steppes. It also shares the sub-endodermal photosynthetic cylinder with this species. It may thus represent an ancient introgession between ssp. perennis and S. fruticosa. The 2 subspecies of $S$. perennis are more closely related, in terms of their DNA and chromosome number, than either of them is to recent hybrids between ssp. perennis and S. fruticosa (Davy et al. 2006). Therefore, sympatric differentiation from a common ancestor with wider tolerances than either current subspecies should also be considered a possibility.

Acknowledgements. We thank F. Fernández-Muñoz for technical assistance. We also thank the Spanish Science and Technology Ministry for its support (project no. CTM200505011). The experiment complied with the current laws of the country in which it was performed.

\section{LITERATURE CITED}

Adams JB, Bate GC (1994) The effect of salinity and inundation on the estuarine macrophyte Sarcocornia perennis (Mill.) A. J. Scott. Aquat Bot 47:341-348

Aschi-Smith S, Chaibi W, Brouquisse R, Ricard B, Saglio P (2003) Assessment of enzyme induction and aerenchyma formation as mechanisms for flooding tolerance in Trifolium subterraneum 'Park'. Ann Bot 61:195-204

Bertness MD (1991) Interspecific interactions among high marsh perennials in a New England salt marsh. Ecology 72:125-137

Blokhina O, Virolainen E, Fagerstedt KV (2003) Sensing and signalling in response to oxygen deprivation in plants and other organisms. Ann Bot 91:179-194

Castellanos EM, Figueroa ME, Davy AJ (1994) Nucleation and facilitation in saltmarsh succession: interactions between Spartina maritima and Arthrocnemum perenne. J Ecol 82:239-248

Castillo JM, Fernández-Baco L, Castellanos EM, Luque CJ, Figueroa ME, Davy AJ (2000) Lower limits of Spartina densiflora and $S$. maritima in a Mediterranean salt marsh determined by different ecophysiological tolerances. J Ecol 88:801-812

Castroviejo S (1990) Sarcocornia. In: Castroviejo S, Lainz M, López González G, Monserrat P, Muñoz Garmendia F, Paiva J, Villar L (eds) Flora Ibérica: plantas vasculares de la Península Ibérica e Islas Baleares. Real Jardín Botánico, CSIC Madrid, p 526-531

Costa CSB, Marangoni JC, Azevedo AMG (2003) Plant zonation in irregularly flooded salt marshes: relative importance of stress tolerance and biological interactions. J Ecol 91:951-965

Davy AJ, Smith H (1985) Population differentiation in the lifehistory characteristics of salt marsh annuals. Vegetatio 61: $117-125$

Davy AJ, Bishop GF, Costa CSB (2001) Biological flora of the British Isles: Salicornia L. (Salicornia pusilla J. Woods, S. ramosissima J. Woods, S. europaea L., S. obscura P. W. Ball \& Tutin, S. nitens P.W. Ball \& Tutin, S. fragilis P. W. Ball \& Tutin and S. dolichostachya Moss). J Ecol 89:681-707

Davy AJ, Bishop GF, Mossman H, Redondo-Gómez S, Castillo JM, Castellanos EM, Luque T, Figueroa ME (2006) Biological Flora of the British Isles: Sarcocornia perennis (Miller) A. J. Scott. J Ecol 94:1035-1048

Figueroa ME, Castillo JM, Redondo S, Luque T and 5 others (2003) Facilitated invasion by hybridization of Sarcocornia species in a salt-marsh succession. J Ecol 91:616-626

Gibbs J, Greenway H (2003) Mechanisms of anoxia tolerance in plants I. Growth, survival and anaerobic catabolism. Funct Plant Biol 30:1-47

Grubb PJ (1977) The maintenance of species richness in plant communities: the importance of the regeneration niche. Biol Rev 52:107-145

Hubbell SP (2006) Neutral theory and the evolution of ecological equivalence. Ecology 87:1387-1398

Jackson MB, Armstrong W (1999) Formation of aerenchyma and the process of ventilation in relation to soil flooding and submergence. Plant Biol 1:274-287

Jackson MB, Colmer TD (2005) Response and adaptation by plants to flooding stress. Ann Bot 96:501-505

Mouillot D, Stubbs W, Faure M, Dumat O, Tomasini JA, Wilson JB, Chi TD (2004) Niche overlap estimates based on quantitative functional traits: a new family of nonparametric indices. Oecologia 145:345-353

Ranwell DS, Bird ECF, Hubbard JCR, Stebbings RE (1964) Spartina salt marshes in Southern England. V. Tidal submergence and chlorinity in Poole Harbour. J Ecol 52:627-641

Redondo S, Rubio-Casal AE, Castillo JM, Luque CJ, Álvarez AA, Luque T, Figueroa ME (2004) Influences of salinity and light on germination of three Sarcocornia taxa with contrasted habitats. Aquat Bot 78:255-264

Redondo-Gómez S, Wharmby C, Moreno FJ, de Cires A, Castillo JM, Luque T, Davy AJ, Figueroa ME (2005) Presence of an internal photosynthetic cylinder surrounding the stele in stems of the tribe Salicornieae (Chenopodiaceae) from SW Iberian Peninsula. Photosynthetica 43:157-159

Redondo-Gómez S, Wharmby C, Castillo JM, MateosNaranjo E and 5 others (2006) Growth and photosynthetic responses to salinity in an extreme halophyte, Sarcocornia fruticosa. Physiol Plantarum 128:116-124

Sánchez JM, Izco J, Medrano M (1996) Relationships between vegetation zonation and altitude in a salt-marsh system in northwest Spain. J Veg Sci 7:695-702

Stribling JM, Glahn OA, Chen XM, Cornwell JC (2006) Microtopographic variability in plant distribution and biogeochemistry in a brackish-marsh system. Mar Ecol Prog Ser 320:121-129 